\title{
Neotropical otter diet variation between a lentic and a lotic systems
}

\author{
Orlando García-Silva ${ }^{1}$, Juan Pablo Gallo-Reynoso ${ }^{2 *}$, Marcos Bucio-Pacheco ${ }^{1}$, José María Medrano-López ${ }^{1}$, Perla Margarita Meza-Inostroza ${ }^{1}$, \\ and Rafael Alejandro Grave-Partida ${ }^{1}$ \\ ${ }^{1}$ Universidad Autónoma de Sinaloa, Unidad Académica de Biología, Departamento de Información y Bibliografía Especializada, \\ Ciudad Universitaria, CP. 80010, Culiacán de Rosales. Sinaloa, México. E-mail: nutriaderio661@gmail.com (GSO), ocelotl@uas. \\ edu.mx (BPM), jose rcv@hotmail.com (MLJ), perinost@gmail.com (MIP), leafaraordnajela@hotmail.com (GPR). \\ ${ }^{2}$ Centro de Investigación en Alimentación y Desarrollo A.C., Unidad Guaymas. Carretera a Varadero Nacional, km 6.6 Col. Las \\ Playitas, CP. 85480, Guaymas. Sonora, México. E-mail: jpgallo@ciad.mx (JPG). \\ *Corresponding author
}

\begin{abstract}
Neotropical otters have been scarcely studied at the northern edge of their distribution in Mexico. The species has nocturnal-twilight habits, and their principal food is fish and crustaceans. The aim of this work was to know the foraging habits of Neotropical otters (Lontra longicaudis) in two monitoring sites one lentic and the other one lotic systems of the Río San Lorenzo, Sinaloa México. From February 2009 to January 2010, we surveyed the area during the four seasons by walking $15 \mathrm{~km}$ of the river edge of Río San Lorenzo, and $15 \mathrm{~km}$ at the El Comedero reservoir. We collected 318 scats, 155 in the reservoir and 163 in the river. Fish were the most abundant prey item in both places, with a frequency of occurrence of $98.1 \%$ in the river and $100 \%$ in the reservoir. The percentage of occurrence varied largely in the other prey items in both places. Seven taxonomic groups compose their foraging habits in the river (relative frequency in parentheses): fish (64.3\%), insects (9.2\%), mollusks (6.8\%), birds (6.0\%), mammals (5.6\%), crustaceans (5.2\%) and fruits (2.8\%). Five taxonomic groups in the reservoir compose it: fish (65.1\%), birds (22.7\%), mammals (9.2\%), fruits (2.5\%) and insects $(0.4 \%)$. The most important fish in the diet belonged to the genus Oreochromis, which includes an introduced species. We conclude that the Neotropical otter is an opportunistic carnivore that preys mainly on fish, probably due to their high availability, but they also forage in other taxa that are available at Río San Lorenzo basin.
\end{abstract}

Las nutrias neotropicales han sido poco estudiadas en el norte de su distribución en México. Esta especie tiene hábitos nocturno-crepusculares, y su principal alimento consiste en peces y crustáceos. El objetivo de este trabajo fue conocer los hábitos alimentarios de la nutria neotropical (Lontra longicaudis) en dos sitios uno léntico y otro lótico del Río San Lorenzo, Sinaloa México. De febrero de 2009 a enero de 2010 , se hicieron recorridos estacionales a pie, $15 \mathrm{~km}$ en el río San Lorenzo y $15 \mathrm{~km}$ en el embalse El Comedero. Se colectaron 318 heces, 155 en el embalse y 163 en el río. En ambos lugares los peces fueron la presa más abundante, con una frecuencia de ocurrencia de $98.1 \%$ en el río y un $100 \%$ en el embalse; para los grupos restantes los porcentajes variaron entre grupos y entre sitios. La alimentación se compuso de siete grupos taxonómicos en el río (entre paréntesis se presenta la frecuencia relativa): peces (64.3\%), insectos (9.2 \%), moluscos (6.8 \%), aves (6.0 \%), mamíferos (5.6\%), crustáceos (5.2\%) y frutos (2.8\%); y de cinco grupos taxonómicos en el embalse: peces (65.1 \%), aves (22.7 \%), mamíferos (9.2 $\%)$, frutos (2.5\%) e insectos (0.4\%). Entre los peces, las presas más importantes correspondieron al género Oreochromis, entre las cuales existe una especie introducida. La nutria neotropical es un carnívoro oportunista, cuyo alimento principal lo constituyen los peces, probablemente debido a su alta disponibilidad y, en menor medida, se alimenta de otros taxones también disponibles en la cuenca del Río San Lorenzo.

Keywords: Foraging habits; Lontra longicaudis; Neotropical otters; Cosalá; Sinaloa.

๑ 2021 Asociación Mexicana de Mastozoología, www.mastozoologiamexicana.org

\section{Introduction}

Energy intake through feeding is essential for metabolic processes like growth and individual physiological maintenance (Saint 2006). Poor nutrition leads to malnutrition, limiting growth in body size (Yom-Tov et al. 2006) and impacting individual performance.

In carnivores, feeding habits are drivers of social organization, habitat use, and reproductive rates, especially when food availability is seasonal (Braña et al. 1987). If food is abundant, the predator can become selective (Young et al. 2008), hunting for those preys that provide the highest amount of energy with the lowest searching effort (Stephens and Krebs 1986). By contrast, if food is scarce, prey diversity increases because predators feed on any prey available (Tinker et al. 2008).
There are different methods for studying the feeding habits of carnivores, including the analysis of scats, direct observations, collection of prey remains in feeders (this option yields limited results by not reflecting the whole range of prey), and stomach content analysis (highly invasive). Of these, scat analysis is the method most commonly used for being non-invasive, relatively easy to analyze, and posing no risk on endangered or threatened species (Marucco et al. 2008). Besides, scat analysis yields information on habitat use, hunting area, trophic niche, home range, behavior, parasitic fauna, heavy metal concentration, and genetic diversity, among other aspects (Chame 2003; Trinca et al. 2007; Josef et al. 2008; Weber et al. 2009; Ramos-Rosas et al. 2013; Guerrero-Flores et al. 2015; Hernández et al. 2018). 
Otters are top predators in aquatic ecosystems (Smiroldo et al. 2009; Prigioni et al. 2006). Lontra longicaudis, one of the four species in the genus, is distributed from northern Mexico to southern Argentina (Gallo-Reynoso 1989; Eisenberg and Redford 1999; Perini et al. 2009; Kasper et al. 2008). The diet of the Neotropical otter have been studied extensively in recent years (Perez-Claros and Palmqvist 2008; Monroy-Vilchis and Mundo 2009; Gallo-Reynoso 1997; Gallo-Reynoso et al. 2008; Rangel-Aguilar and GalloReynoso 2013), reporting the local availability of its potential prey, as well as the morphological, behavioral, and physiological adaptations allowing otters to locate, capture, and ingest biomass from a wide variety of species (Kok and $\mathrm{Nel}$ 2004). In general, these studies indicate that its main diet consists of fish and crustaceans (Gallo-Reynoso 1989; 1997; Macías-Sánchez 1999; Casariego-Madorell et al. 2006); however, this opportunistic predator occasionally feeds on reptiles, amphibians, insects, birds, and small mammals such as mice (Gallo-Reynoso 19899; Gallo-Reynoso et al. 2008), and even on insects (Rangel-Aguilar and Gallo-Reynoso 2013). Because of its relative selectivity, the Neotropical otter is considered a bioindicator of well-conserved aquatic ecosystems (Lodé 1993).

There are no specific studies on this species in Sinaloa. Its presence has been reported in Ahome and Escuinapa,
El Verde estuary (Gallo-Reynoso and Navarro-Serment, personal observation 2002) and El Fuerte River and its dams (Gallo-Reynoso, unpublished data), as well as in Durango rivers flowing to Sinaloa, such as the San Diego river (Cruz et al. 2017) and Mezquital and San Pedro rivers (Servin et al. 2003; Charre-Medellín et al. 2011). Studies to define its current distribution and conservation status in Sinaloa are needed because this area is close to its northern distribution limit. This paper aims to determine the diet composition of the Neotropical otter at two locations in the State of Sinaloa, namely El Comedero dam a lentic system and the San Lorenzo River a lotic system, during one year to explore any variability in the otter's diet associated with the climatic seasons. This study will provide data on the distribution of the Neotropical otter and the characteristics of aquatic ecosystems in Sinaloa, which could be used in management plans for the conservation of the species and the maintenance of river water quality.

\section{Materials and Methods}

Study Area. The work was carried out on the San Lorenzo river that drains its waters into the José López Portillo dam (locally known as El Comedero), a reservoir shared between the States of Durango and Sinaloa. The San Lorenzo river basin is located in the Sierra Madre Occidental, running

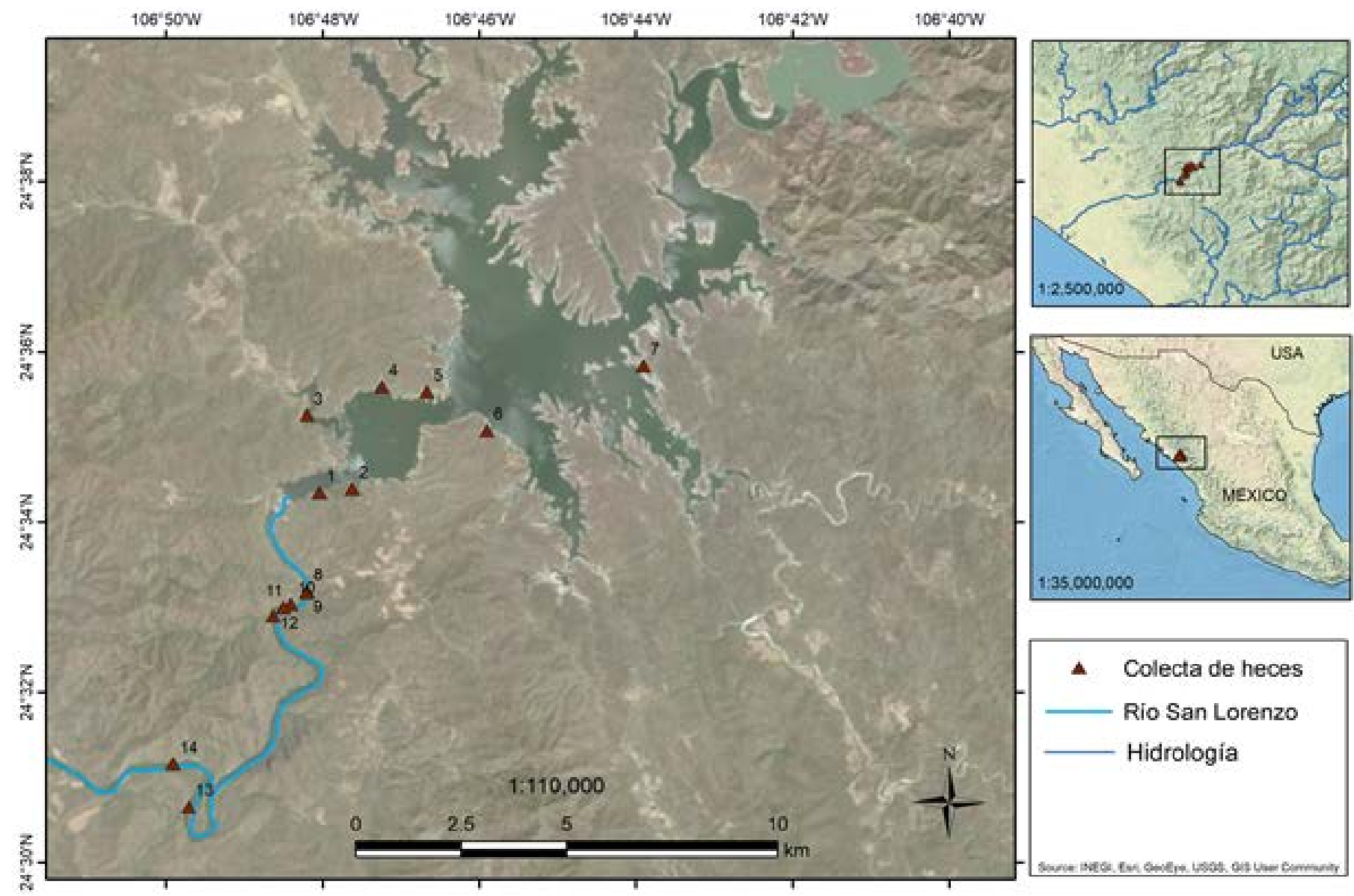

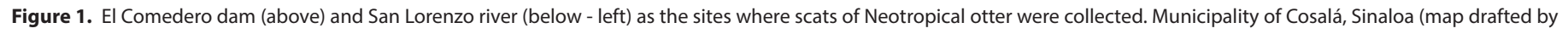
Gloria Ponce García). 
across parts of Sinaloa and Durango and catching runoff waters from summer rains. Both study sites are located in the municipality of Cosalá, Sinaloa. The dam a lotic system, is located at an altitude of 258 meters above sea level, centered geographically at $24^{\circ} 35^{\prime} 03.8^{\prime \prime} \mathrm{N}$ and $-106^{\circ} 45^{\prime} 53.4^{\prime \prime}$ W; the study site on the San Lorenzo River a lotic system is located downstream at 168 meters above sea level, with a geographic center located at the coordinates $24^{\circ} 33^{\prime} 07.4^{\prime \prime} \mathrm{N}$ and $-106^{\circ} 48^{\prime} 12.8^{\prime \prime} \mathrm{W}$ (Figure 1).

The dominant vegetation on the riverbanks corresponds to low deciduous forest (classification of Miranda and Hernández 1963) or deciduous tropical forest (classification of Rzedowski 1978). Its most representative species include mauto (Lysiloma divaricata), amapa (Tabebuia palmeri), palo blanco (Ipomoea arboressen), pochote (Ceiba acuminata), papelillo (Bursera grandifolia), Brazilwood (Haematoxyllum brasiletto), mora (Chlorophora tinctoria) and yellow rose (Cochlopermum vitium). Common animal species include carnivores such as coyote (Canis latrans), coatí (Nasua narica), raccoon (Procyon lotor), gray fox (Urocyon cinereoargenteus), capixtle (Bassariscus astutus), bobcat (Lynx rufus), cougar (Puma concolor), jaguar (Panthera onca), ocelot (Leopardus pardalis), margay (Leopardus wiedii), jaguarundi (Puma yaguarundi), and skunks (Conepatus leuconotus, Mephitis macroura, and Spilogale sp.). Ungulates include the white-tail deer (Odocoileus virginianus) and the necklace peccari (Pecari tajacu). Chachalaca (Ortalis poliocephala) and other birds are common to this type of vegetation. Riverbank vegetation includes Ficus and Salix as the most representative genera, as well as vines. Riverbank vegetation comprises some a strip of land stretching 15 to $20 \mathrm{~m}$ from the riverbank, with deciduous tropical forests growing farther inland.

Sample Collection. Seasonal sampling was carried out at each study site to represent the different climatic seasons and explore any seasonal variations in the diet of otters. We selected one month as representative of each climatic season (spring, summer, autumn, and winter). Sampling was carried out by walking along the riverbank and collecting any otter scats found that could be quantified as a single unit, i.e., complete scats that could be determined as otter scats with certainty. Otter scats were identified based on their dark color with a slight musk odor when fresh, or whitish when dry, and visibly composed of fish scales, insect legs, prawn or shrimp heads, fragments of crab exoskeletons, fruit seeds, pastures, organic matter, etc. Individual scat samples were stored in self-sealing plastic bags labeled with the geographic location of the sample as recorded with a manual geopositioner (GPS). In the dam, the sites for scat collection were marked considering a separation of approximately $3 \mathrm{~km}$ between them.

Sample Analysis. Scat samples were transferred to the Zoology Laboratory at Universidad Autónoma de Sinaloa (Culiacan Campus) for analysis. Once in the lab, samples were immersed in soapy water for 48 hours, then rinsed and screened through a $1 \mathrm{~mm}$ mesh to remove digested organic matter and other soluble materials. The hard remains of preys contained in scats were sorted using dissecting needles and forceps; these were dried in an oven at $60^{\circ} \mathrm{C}$ for 48 hours and stored in labeled bottles or self-sealable bags until analysis. For species other than fish (i.e., invertebrates, birds, mammals, reptiles, amphibians, etc.), the remains were observed under a stereomicroscope for identification aided with guides and catalogs (García and Ceballos 1994). In the case of fish, scales and vertebrae found in scats were compared (based on morphological traits) with the respective parts of fish collected from the sampling sites as reference material. Fish were collected by local fishers using seine nets (locally called chinchorro), hooks, fishing rods, and by freediving with rudimentary harpoons.

For each prey species identified, the frequency of occurrence $(F O)$ was estimated as: $F O=F E / N$, where $F E_{i}$ is the total number of samples showing species $i$ and $N$ is the total number of samples. The percentage of occurrence $(P O)$ of each prey category was estimated according to Maher and Brady (1986) as modified by Gallo-Reynoso and GarcíaAguilar (2008): $P O=F C i \times 100 / \Sigma F$, where $F C_{i}$ is the total frequency of the prey $i$ and $F$ is frequency.

The differences in the otter's diet (number and identity of prey species) between the two water bodies studied were explored with the Bray-Curtis Dissimilarity Index (Bray and Curtis 1957). This index is commonly used to quantify the difference in the number of species between two sites. In this case, it was used to determine the magnitude of the difference in the otter's diet (number of elements in the diet) in both water bodies. The Bray-Curtis dissimilarity figure ranges between 0 and 1, where 0 (zero) indicates total similarity of elements in the diet in both sites, while 1 (one) indicates that the diet is completely dissimilar (i.e., it shares no common elements) in the two sites. The values obtained are usually multiplied by 100 to report them as percent dissimilarity. The Bray-Curtis dissimilarity index is calculated as: $B C_{i j}=1-2 C_{i j} / S_{i}+S$, where $i$ and $j$ are the two sites, $S i$ is the total number of species at site $I$, and $S j$ is the number of species at site $j$. Cij is the sum of the lowest counts for each species found in both sites.

Finally, the Schoener index (Schoener 1974) was used to determine the diet overlap between the dam and San Lorenzo river (using the data in Table 1) to explore the potential effect of reservoir waters on the overall composition of the diet. According to the Schoener index, a value of 0 indicates no overlap, values close to 1 suggest marked overlap, and 1 indicates complete overlap. Overlap values above 0.6 are considered biologically relevant. $C_{x y}$ estimates the overlap in the diet between the dam ( $x i)$ and the river (yi). $P$ is the proportion of total resources in the diet in the dam (xi) and the river (yi). $C_{x y}=1-0.5\left(\Sigma\left|p_{x i}-p_{y i}\right|\right)$.

\section{Results}

Frequency of Occurrence. A total of 318 scat samples were collected, from which food items belonged to seven taxonomic groups: mammals, birds, fish, crustaceans, insects, 
mollusks, and fruits. Of these groups, only five were found in the dam, where no mollusks and crustaceans were observed. In both sites, fish were the dominant food item in the otter's diet, with a frequency of occurrence of 98.1 $\%$ in the river and $100 \%$ in the dam. The percentage of occurrence of the remaining food types varies considerably; for example, insects were the second most frequent group (14.1\%) in the river, whereas they made a mere $0.6 \%$ in the dam. The groups not detected in dam scats were mollusks and crustaceans, which attained frequencies of $10.4 \%$ and $7.9 \%$, respectively, in the river. Seeds accounted for $3.8 \%$ of food items in the dam and $4.2 \%$ in the river (Table 1).

Dietary Dissimilarity. According to the Bray-Curtis index, the dissimilarity in the otter's diet between the water bodies studied was not significant, with 0.205 (i. e., a difference of $20.5 \%$ ), suggesting that the feeding habits of otters were not markedly different in the two water bodies.

Diet Overlap. The Schoener overlap index showed a nonsignificant difference between the two water bodies, with 0.85 , indicating that the otter's diet is highly overlapped in both water bodies. However, there are some differences regarding some elements of the diet (refer to the following section).

Identification of Prey Species. Most of the prey species identified were fish. In both the dam and the river, mojarra or tilapia (Oreochromis sp.) was the fish species showing the highest percentage of occurrence, with $90.8 \%$ in the river and $98.1 \%$ in the dam. This was followed by the carp (Суprinus carpio, $46 \%$ and $56.8 \%$ ) and, in smaller percentages, largemouth bass (Micropterus salmoides), catfish (Ictalurus sp.), and charal (Dorostoma smithi; Table 1).

In the river, the group that ranked second in importance after fish were insects. Of these, the family Tettigoniidae (Orthoptera) had a percentage of occurrence of $9.2 \%$, followed by unidentified coleopterans with $6.7 \%$, and the family Gryllidae (Orthoptera) with $2.5 \%$. In the dam, the most abundant group after fish was birds (which were not identified), with $34 \%$; a significant difference was observed versus the river, where birds represented only $9.2 \%$.

As for mammals, we recorded field mouse remains, representing $8.2 \%$ in the river and $14.2 \%$ in the dam. The river prawn Macrobrachium americanum and the river snail (unidentified Gasteropoda) were absent in scat samples from the dam but were found in river samples with frequencies of $8.0 \%$ and $9.2 \%$, respectively. Seeds of guamúchil, $P$. dulce, were observed at lower frequencies, $4.3 \%$ in the river and $0 \%$ in the dam; to note, $10 \%$ of the seeds found in otter scats could not be identified.

Table 1. Number of occurrences (NO), frequency of occurrence (FO), and percentage of occurrence (PO) of the supra-specific taxonomic groups and species in the otter diet, from 318 scat samples collected in the San Lorenzo river and El Comedero dam, municipality of San Juan Cosalá, Sinaloa.

\begin{tabular}{|c|c|c|c|c|c|c|c|c|}
\hline \multirow[b]{2}{*}{ Species } & \multicolumn{4}{|c|}{ San Lorenzo River } & \multicolumn{4}{|c|}{ El Comedero dam } \\
\hline & & NO & FO & PO & & NO & FO & PO \\
\hline FISH & & 160 & 64.3 & 98.2 & & 155 & 65.1 & 100 \\
\hline Tilapia (Oreochromis sp) & & 148 & & 90.8 & & 152 & & 98.1 \\
\hline Bass (Micropterus salmoides) & & 35 & & 21.5 & & 46 & & 29.7 \\
\hline Catfish (Ictalurus sp) & & 27 & & 16.6 & & 37 & & 23.9 \\
\hline Carp (Cyprinus carpio) & & 75 & & 46.0 & & 88 & & 56.8 \\
\hline Charal (Dorostoma smithi) & & 0 & & 0 & & 15 & & 9.7 \\
\hline INSECTS & & 23 & 9.2 & 14.1 & & 1 & 0.4 & 0.6 \\
\hline Grasshopper: Tetigonidae & & 15 & & 9.2 & & 1 & & 0.6 \\
\hline Coleoptera: Unidentified & & 11 & & 6.7 & & 0 & & 0 \\
\hline Crickets: Grillidae & & 4 & & 2.5 & & 0 & & 0 \\
\hline MOLLUSKS & & 17 & 6.8 & 10.4 & & 0 & 0 & 0 \\
\hline River snail: Unidentified & & 15 & & 9.2 & & 0 & & 0 \\
\hline Bivalve: Unidentified & & 2 & & 1.2 & & 0 & & 0 \\
\hline BIRDS & & 15 & 6.1 & 9.2 & & 54 & 22.7 & 34.8 \\
\hline Unidentified birds & & 15 & & 9.2 & & 54 & & 34.8 \\
\hline MAMMALS & & 14 & 5.6 & 8.6 & & 22 & 9.2 & 14.2 \\
\hline Unidentified mice & & 14 & & 8.6 & & 22 & & 14.2 \\
\hline CRUSTACEANS & & 13 & 5.2 & 8.0 & & 0 & 0 & 0 \\
\hline River prawn: Macrobachium americanum & & 13 & & 8.0 & & 0 & & 0 \\
\hline PLANTS (FRUITS) & & 17 & 2.8 & 10.4 & & 6 & 2.6 & 3.9 \\
\hline Guamuchil: Pithecellobium dulce & & 7 & & 4.3 & & 0 & & 0 \\
\hline Unidentified & & 10 & & 6.1 & & 6 & & 3.9 \\
\hline Total SAMPLES & 163 & & & & 155 & & & \\
\hline
\end{tabular}


Seasonal Variation. The months selected were those with no minor differences in the number of samples collected. Accordingly, we analyzed 66 samples from the dam and 65 from the river (Tables 2, 3).

Regarding the proportion of groups and species, a marked difference was found both between seasons and between the two sites (Tables 2, 3). In the dam, fish showed no variations, as they were recorded in the same proportion of the diet in the four seasons, although with fluctuations in the proportion of species. Oreochromis sp. remained stable at $50 \%$ in spring and summer, increasing to $92 \%$ in autumn and then decreasing to $63 \%$ in winter. Fish and birds were identified in all seasons, with significant variations between them. Insects and plants were found in otter scats only in the spring, with $5 \%$ each.

\section{Discussion}

Prey Abundance. This work supports the hypothesis that the otter is a predominantly ichthyophagous species (GalloReynoso 1989, 1997; Macías-Sánchez 1999; Perini et al. 2009), as fish were the most abundant food item in the diet of otters, both in the river and in the reservoir. The predominance of fish in otter scats could be either a direct indicator of its dietary preferences or a reflection of the local abundance of their different types of prey (Gallo-Reynoso 1989 and 1997; Rangel-Aguilar and Gallo-Reynoso 2013). Birds, mammals, and insects are also groups of greater importance than crustaceans. These differences may reflect the relative availability of each of these groups due to the type of ecosystem they inhabit. In addition, we found two species of plants whose fruits were consumed by otters.

Similar results supporting the predominance of ichthyophagous feeding habits have been recorded for Lontra longicaudis, as fish represented $93 \%$ in southern Mexico (GalloReynoso 1989) and Costa Rica (Pardini 1998), and $50 \%$ to
$85 \%$ in southern Brazil (Quadros and Monteiro-Filho 2001). This was also the case for Lutra lutra, with fish representing $88 \%$ of the diet in Scotland (Durbin 1997), and Lutra perspicillata, with $92 \%$ in India (Anoop and Hussain 2005).

Several works on the feeding habits of the otter report crustaceans, particularly river prawn (M. americanum), as an important component in the diet (Gallo-Reynoso 1989 and 1997; Pardini 1998; Casariego-Madorell et al. 2006). Crustaceans were the second-most important group, even being the main food type consumed by otters in some smaller rivers (Gallo-Reynoso 1989 and 1997).

On the other hand, insects are an important component of the diet of $L$. longicaudis, only second to fish in the river. Three taxa, Coleoptera, Orthoptera, and Grilleidae, of which only coleopterans (Gallo-Reynoso 1997) and crickets (Rangel-Aguilar and Gallo-Reynoso 2013) had been reported, were identified in this category.

This feeding behavior of the otter is consistent with the optimal foraging theory (Stephens and Krebs 1986). This theory predicts that a predator will feed preferentially on the most abundant organism because of the ease of capture involving minimum energy expenditure; however, the same outcome is predicted when the most energy-profitable prey is also the most abundant one. Thus, the otter could be either behaving according to optimal foraging or forage opportunistically on the most abundant prey, similar to the coyote (Canis latrans; Boutin and Cluff 1989). The optimal foraging theory (Stephens and Krebs 1986) also predicts that an individual predator will become selective towards the prey providing the highest energy profit per unit of energy spent in the capture (Charnov 1976; Pyke et al. 1977; Stephens and Krebs 1986). This is what we would expect if species that are more energy-profitable become available. In the present study, the bass would be the most energy-profitable prey because of its larger size relative to

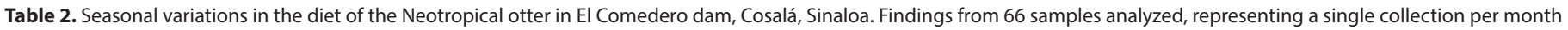
and climatic season. Data shown are the percentage of occurrence, with the frequency of occurrence (FO) in parentheses.

\begin{tabular}{|c|c|c|c|c|}
\hline Group and species occurrences & Spring & Summer & Fall & Winter \\
\hline & $(n=20)$ & $(n=10)$ & $(n=14)$ & $(n=22)$ \\
\hline Fish (FO) & $n=140(7)$ & $n=190(19)$ & $n=143(10.2)$ & $n=113(5.1)$ \\
\hline Oreochromis sp. (FO) & 35.7 & 26.3 & 92.8 & 63.6 \\
\hline Ictalurus sp. (FO) & 21.4 & 10.6 & 28.5 & 18.1 \\
\hline Micropterus salmoides (FO) & 25 & 36.8 & 7.1 & 13.6 \\
\hline Cyprinus carpio (FO) & 17.9 & 26.3 & 14.2 & 18.1 \\
\hline Birds (FO) & $n=35(1.8)$ & $n=50(5)$ & $n=43(3.1)$ & $n=32(0.7)$ \\
\hline Unidentified (FO) & 35 & 50 & 42.8 & 31.8 \\
\hline Mammals (FO) & $n=15(0.8)$ & & & \\
\hline Mice (FO) & 15 & & & \\
\hline Insects (FO) & $n=5(0.3)$ & & & \\
\hline Grillidae (FO) & 5 & & & \\
\hline Plants (fruits) (FO) & $n=5(0.3)$ & & & \\
\hline Unidentified (FO) & 5 & & & \\
\hline
\end{tabular}


tilapia; indeed, this species predominates in otter scats in summer, in both the river and the dam.

Identification of Prey Species. Tilapia, Oreochromis sp., which is an introduced fish, is the most important prey for the Neotropical otter, attaining the highest frequency in scats, besides clearly being the most available species, with various growth stages observed. This species has been reported in other works, albeit not as the most abundant species (GalloReynoso et al. 2008; Rangel-Aguilar and Gallo-Reynoso 2013). The largemouth bass ( $M$. salmoides) and other salmonids (Crait and Ben-David 2006), as well as cyprinids, have been reported as the groups of fish most consumed by several species of otters (Britton and Shepherd 2005; Crait and Ben-David 2006). In contrast, the charal (D. smithi) had not been previously recorded as a prey of $L$. longicaudis.

As for plants (fruits), those consumed by otters include Myrtaceas, Sapotaceae, and Rubiaceae (Quadros and Monteiro-Filho 2001), as well as remains of cultivated plants such as papaya (Gallo-Reynoso 1989; Kasper et al. 2008). However, there are no previous records of guamúchil ( $P$. dulce), which was found with a frequency of $4.1 \%$ in scats collected in the river, along with other unidentified seeds. Two of the invertebrate species found - a gastropod and a bivalve - could not be identified for lack of published studies on them, although both have been reported previously by Rangel-Aguilar and Gallo-Reynoso (2013).

There are records of field mice as prey of otters (GalloReynoso 1997; Pardini 1998), but the species found in the present study could not be identified because it was represented by long bone fragments only.

Seasonal Variation. Seasonal variations in the diet composition of the Neotropical otter have been reported (Gori et al. 2003; Kasper et al. 2008), a finding that was confirmed in this study. In summer alone, the composition of the diet in the river varied in terms of the proportion of fish species. In all other stations in both sites, this parameter showed a stable behavior. This is likely because fish are highly available, with different growth stages observed; an alternative explanation is that the otter specifically forages on them because the energy and time employed in capturing them is compensated by the amount of energy provided by these organisms (Pyke et al. 1977; Hernández et al. 2002).

In the dam, the main prey was Oreochromis sp. This species was observed in high frequencies in otter scats throughout the year, being constant in spring-summer and increasing in frequency in autumn-winter, which is when the largemouth bass, $M$. salmoides (a top predator in the fish food chain), shows lower frequencies of occurrence. The shortage of bass in the diet was compensated by an

Table 3. Seasonal variations in the feeding habits of the Neotropical otter in El Comedero dam, Cosalá, Sinaloa. Findings from 65 samples analyzed, representing a single collection per month and climatic season. Data shown are the percentage of occurrence, with the frequency of occurrence (FO) in parentheses.

\begin{tabular}{|c|c|c|c|c|}
\hline Group and species occurrences & Spring & Summer & Fall & Winter \\
\hline & $(n=20)$ & $(n=21)$ & $(n=12)$ & $(n=12)$ \\
\hline Fish (FO) & $n=110(5.5)$ & $n=153(7.3)$ & $n=84(7)$ & $n=117(9.8)$ \\
\hline Oreochromis sp. (FO) & 55 & 48 & 59 & 59 \\
\hline Ictalurus sp. (FO) & 5 & & 25 & 17 \\
\hline Micropterus salmoides (FO) & 30 & 76 & & 41 \\
\hline Cyprinus carpio (FO) & 20 & 29 & & \\
\hline \multicolumn{5}{|l|}{ Dorostoma smithi (FO) } \\
\hline Birds (FO) & $n=20(1)$ & & & $n=8(0.7)$ \\
\hline Unidentified (FO) & 20 & & & 8.3 \\
\hline Mammals (FO) & 5 & & 8.3 & \\
\hline Mice (FO) & 5 & & 8.3 & \\
\hline Insects (FO) & $n=30(1.5)$ & $n=5(0.2)$ & $n=17(1.4)$ & \\
\hline Coleoptera (FO) & 30 & 4.7 & & \\
\hline Tetigonidae (FO) & & & 16.6 & \\
\hline \multicolumn{5}{|l|}{ Grillidae (FO) } \\
\hline Mollusks (FO) & $n=35(1.8)$ & $n=5(0.2)$ & $n=17(1.4)$ & $n=17(1.4)$ \\
\hline Gasteropod (FO) & 35 & & 8.3 & 16.6 \\
\hline Bivalve (FO) & & 4.7 & 8.3 & \\
\hline Crustaceans (FO) & & $n=33(1.6)$ & & \\
\hline Macrobrachium americanum (FO) & & 33 & & \\
\hline Plants (fruits) (FO) & $n=15(0.8)$ & $n=14(0.7)$ & $n=8(0.6)$ & \\
\hline Pithecellobium dulce (FO) & & 14.2 & & \\
\hline Unidentified (FO) & 15 & & 8.3 & \\
\hline
\end{tabular}


increased consumption of Oreochromis sp. In autumn, the frequency of tilapia in otter scats increased to $92.8 \%$ and charal (D. smithi) was absent.

In the river, the tilapia remains as a nearly constant prey, with no noticeable changes in frequency; it showed a slight increase in autumn when bass and carp were completely absent as prey. The bass occurred in springsummer, being more abundant in summer - the season when catfish Ictalurus $\mathrm{sp}$ were not recorded. No charal was observed in the river.

In the river, insects made up an important part of the diet of otters; however, these were insignificant in the dam, with only traces of insects found in a single sample of otter scats. This suggests that otters are capable of adapting to altered environments such as dams, and although there is no presence of insects in their diet, they can modify their diet by predating on species that are in greater availability.

The absence of mollusks and crustaceans in scat samples collected in the dam may be due to their absence in this site. Other scenarios are that these invertebrates are present, but otters do not feed on them due to the high abundance of fish, or these invertebrates are hard to capture by otters because they probably occur in deep habitats that are hard to access since the dam is deeper than the river.

Birds were twice as frequent in otter scats in the dam relative to the river, similar to the findings reported by GalloReynoso et al. (2008). This suggests a higher diversity and availability of aquatic birds in the dam or that birds use the greater area of the dam than the river.

In this study, the diet of the Neotropical otter included seven taxonomic groups in the San Lorenzo river and five in El Comedero dam, with fish showing the highest percentage of occurrence in both sites. These results are consistent with works conducted for this same species in southern and northern Mexico (Gallo-Reynoso 1989, 1997; Macías-Sánchez 1999; Rangel-Aguilar and Gallo-Reynoso 2013) and in other countries (Pardini 1998; Quadros and Monteiro-Filho 2001; Perini et al. 2009).

Finally, a biologically significant difference was found with the Schoener index (Schoener 1974) as to the species that make up the diet of the Neotropical otter; this is expected because the diversity of prey in the lentic system (dam) is much lower than in the lotic system (river).

The Neotropical otter shares the riparian habitat with the gray fox (Urocyon cinereoargenteus), the coatí (Nasua narica), and the raccoon (Procyon lotor), and resembles the latter in the consumption of crustaceans and insects. Most otter latrines also showed mingled scats from gray fox, coati, and raccoon. This may be explained by the musk odor in otter scats that attract these other carnivorous species to mark the territory or display a communication behavior similar to that of otters (Gallo-Reynoso et al. 2016).

This work underlines the importance of the Neotropical otter as a bioindicator of the presence of other species in water bodies, including mollusks, crustaceans, insects, and fish on which they feed. At the same time, otters act as umbrella species. As top predators in water bodies of northwestern Mexico, these indicate the presence of a certain diversity of species in these environments, therefore suggesting that they are suitable for use as an indicator of the good conservation status of these ecosystems.

\section{Acknowledgments}

The authors wish to thank G. Ontiveros Crespo and J. L. Medina Carrasco for their assistance in the field, as well as to A. García Silva for support as a field guide. Thanks also to the School of Biology at Universidad Autónoma de Sinaloa for the use of the Zoology Laboratory, where samples were processed. Thanks to G. Ponce García for drawing up Figure 1. The comments of two anonymous reviewers and the Associate Editor contributed to improving the manuscript. M. E. Sánchez-Salazar translated the manuscript into English.

\section{Literature cited}

Anoop, K. R., And S. A. Hussain. 2005. Food and feeding habits of smooth-coated otters (Lutra perspicillata) and their significance to the fish population of Kerala, India. Journal of Zoology 266:15-23.

Azevedo, F. C. C., V. Lester, W. Gorsuch, A. S. Lariviere, and J. W. D. L. MurRaY. 2005. Dietary breadth and overlap among five sympatric prairie carnivores. Zoology 269:127-135.

Boutin, S., AND H. D. Cluff. 1989. Coyote prey choice; optimal or opportunistic foraging? A comment. Wildlife Management 53:663-666.

Braña, F., J. Naves, and G. Palomero. 1987. Hábitos alimenticios y configuración de la dieta del oso pardo en la cordillera cantábrica. Coloquio Internacional sobre el oso pardo 1:14-15.

BraY, J. R., AND J. T. CURTIS. 1957. An ordination of upland forest communities of southern Wisconsin. Ecological Monographs 27:325-349.

Britton, J. R., ANd J. S. Shephered. 2005. Presence of carp, Cyprinus carpio, in the diet of the otter, Lutra lutra. Fisheries Management and Ecology 12:221-223.

Casariego-Madorell, M. A., R. List, and G. Ceballos. 2006. Aspectos básicos sobre la ecología de la nutria de río (Lontra longicaudis annectens) para la costa de Oaxaca. Revista Mexicana de Mastozoología 10:71-74.

CRaIt, J. R., And M. Ben-David. 2006. River otters in Yellowstone lake depend on a declining cutthroat trout population. Journal of Mammalogy 87:485-494.

Cruz García, F., A. J. Contreras Balderas, J. A. García Salas, and J. P. Gallo-Reynoso. 2017. Dieta de la nutria neotropical (Lontra longicaudis annectens) en Pueblo Nuevo, Durango, México. Revista Mexicana de Biodiversidad 88:701-709.

Charre-Medellín, J. F., C. López-González, A. Lozano, and A. F. GuzMÁn. 2011. Conocimiento actual sobre la nutria neotropical (Lontra longicaudis annectens) en el estado de Durango. Revista Mexicana de Biodiversidad 82:1343-1347.

Chame, M. 2003. Terrestrial Mammal Feces: a Morphometric Summary and Description. Memórias do Instituto Oswaldo Cruz 98:71-94. 
Charnov, E. L. 1976. Optimal foraging: attack strategy of a mantid. The American Naturalist 110:141-151.

Durbin, L. S. 1997. Composition of salmonid species in the estimated diet of otters (Lutra lutra) and in electrofishing catches. Journal of Zoology 243:821-825.

EisenberG, J. F., ANd K. H. Redford. 1999. Mammals of the Neotropics: The Central Neotropics. The University of Chicago Press. U.S.A.

Foster-Turley, P., S. Macdonald, and C. Mason. 1990. Otters: An Action Plan for their Conservation. IUCN - Otter Specialist Group. Gland Switzerland.

Gallo-Reynoso, J.P. 1989. Distribución y estado actual de la nutria o perro de agua (Lutra longicaudis annectens Major, 1897) en la Sierra Madre del Sur, México. Tesis de Maestría. Facultad de Ciencias, UNAM. 236 p. Disponible en:jpgallo@ciad.mx

Gallo-Reynoso, J. P. 1997. Situación y distribución de las nutrias de México, con énfasis en Lontra longicaudis annectens MAJOR, 1897. Revista Mexicana de Mastozoología 2:10-32.

Gallo-Reynoso, J. P., N. N. Ramos-Rosas, and O. Rangel-AguiLAR. 2008. Aquatic bird predation by Neotropical river otter (Lontra longicaudis annectens), at Río Yaqui, Sonora, México. Depredación de aves acuáticas por la nutria neotropical (Lontra longicaudis annectens), en el río Yaqui, Sonora, México. Revista Mexicana de Biodiversidad 79:275-279.

Gallo-Reynoso, J. P., And M. C. García-Aguilar. 2008. Análisis preliminar de la presencia de perros ferales en la Isla Cedros, Baja California. Revista Mexicana de Mastozoología 12:130-140.

Gallo-Reynoso, J. P., S. Macías-Sánchez, L. Armenta-Méndez, I. Barba-Acuña, V. A. Nuñez-Ramos, A. Loya-Jaquez, G. PonceGarcía, And A. Gardea-Béjar. 2016. Letrinas de nutrias y cámaras trampa ¿qué nos dicen? XIII Congreso Nacional de Mastozoología, Tuxtla Gutiérrez, Chiapas. 24 a 28 de Octubre. Disponible en: jpgallo@ciad.mx

García, A., And G. Ceballos. 1994. Guía de campo de los reptiles y anfibios de la costa de Jalisco, México. Fundación Ecológica de Cuixmala, A.C. e Instituto de Biología, UNAM. Ciudad de México.

Glen, A. S., AND C. R. Dickman. 2008. Niche overlap between marsupial and eutherian carnivores: does competition threaten the endangered spotted-tailed quoll? Applied Ecology 45:700-707.

Gori, M., G. M. Carpaneto, And P. Ottino. 2003. Spatial distribution and diet of the Neotropical otter Lontra longicaudis in the Ibera Lake (northern Argentina). Acta Theriologica 48:495-504.

Guerrero-Flores, J. J., J. P. Gallo-Reynoso, And R. Biek. 2015. Mitochondrial DNA diversity, genetic structure, and demographic history of the Neotropical Otter (Lontra longicaudis) in Mexico. (JMAMM2014048.R2) Published on line in the Journal of Mammalogy 96:1162-1173.

Hardin, G. 1960. The Competitive Exclusion Principle. Science 131:1292-1297.

Hernández, L., R. R. Parmenter, J. W. Dewitt, D. C. Lightfoot, and J. W. Laundre. 2002. Coyote diets in the Chihuahuan Desert, more evidence for optimal foraging. Arid Environments 51:613-624.

Hernández-Romero, P. C., C. Gutiérrez-Rodríguez, C. Valdespino, and D. A. Prieto-Torres. 2018. The Role of Geographical and Ecological Factors on Population Divergence of the Neotropical otter Lontra longicaudis (Carnivora, Mustelidae). Evolutionary Biology 45:37-55.
Josef, C. F., L. R. Adriano, E. J. De Frañasa, G. G. Arantes De CarVAlho, AND J. R. Ferreira. 2008. Determination of $\mathrm{Hg}$ and diet identification in otter (Lontra longicaudis) feces. Environmental Pollution 152:592-596.

Kasper, C. B., V. A. G. Bastazini, J. Salvi, and H. C. Z. Grillo. 2008. Trophic ecology and the use of shelters and latrines by the Neotropical otter (Lontra longicaudis) in the Taquari Valley, Southern Brazil. Iheringia, Série Zoologia 98:469-474.

Koк, O. B., AND J. A. J. Nel. 2004. Convergence and divergence in prey of sympatric canids and felids: opportunism or phylogenetic constraint? Biological Journal of the Linnean Society 83:527-538.

LoDÉ, T. T. 1993. The decline of otter Lutra lutra populations in the region of the Pays de Loire, western France. Biological Conservation 65:9-13.

Macías-Sánchez, S., And M. Aranda. 1999. Análisis de la alimentación de la nutria Lontra longicaudis (Mammalia: Carnivora) en un sector del Río Los Pescados, Veracruz, México. Acta Zoológica Mexicana (nueva serie) 76:49-57.

Maher, D. S., AND J. R., Brady. 1986. Food habits of bobcat in Florida. Journal of Mammalogy 67:133-138.

Marucco, F., D. H. Pletscher, And L. Boitani. 2008. Accuracy of scat sampling for carnivore analysis: wolves in the Alps as a case study. Mammalogy 89:665-673.

Miranda, F., And E. Hernández. 1963. Los tipos de vegetación de México y su clasificación. Boletín de la Sociedad Botánica de México 28:29-179.

Mitchell, B. D., And P. B. Banks. 2005. Do wild dogs exclude foxes? Evidence for competition from dietary and spatial overlaps. Austral Ecology 30:581-591.

Monroy-VILchis, O., AND V. Mundo. 2009. Food niche of the neotropical river otter (Lontra longicaudis) in a modified environment, Temascaltepec, México. Revista Mexicana de Biodiversidad 80:801-806.

NowaK, R. M. 1991. Walker's mammals of the world. London.

Pardini, R. 1998. Feeding ecology of the neotropical river otter Lontra longicaudis in an Atlantic Forest stream, south-eastern Brazil. Journal of Zoology 245:385-391.

Perez-Claros, J. A., And P. Palmovist. 2008. How many potential prey species account for the bulk of the diet of mammalian predators? Implications for stable isotope paleodietary analyses. Zoology 275:9-17.

Perini, A. A., E. M. Vieira, and U. H. Schulzb. 2009. Evaluation of methods used for diet analysis of the Neotropical otter Lontra longicaudis (Carnivora, Mustelidae) based on spraints. Mammal Biology 74:230-235.

Prigioni, C., A. Balestrieri, L. Remonti, A. Gargaro, and G. Priore. 2006. Diet of the Eurasian otter (Lutra lutra) in relation to freshwater habitats and alien fish species in southern Italy. Ethology Ecology and Evolution 18:307-320.

Pyke, G. H., H. R. Pulliam, and E, L, Charnov. 1977. Optimal foraging: a selective review of theory and tests. The Quarterly Review of Biology 52:137-154.

Quadros, J., And E. L. A. Monteiro-Filho. 2001. Diet of the Neotropical otter, Lontra longicaudis, in an Atlantic forest area, Santa Catarina State, southern Brazil. Studies on Neotropical Fauna and Environment 36:15-21.

Ramos-Rosas, N., C. Valdespino, J. García Hernández, J. P. GalloReynoso, And E. Olguín. 2012. Heavy metals in the habitat and 
throughout the food chain of the Neotropical otter, Lontra longicaudis, in protected Mexican wetlands. Environmental Monitoring and Assessment 184:1-11.

Rangel-Aguilar, O., And J. P. Gallo-Reynoso. 2013. Hábitos alimentarios de la nutria neotropical (Lontra longicaudis annectens) en el Río Bavispe-Yaqui, Sonora, México. Feeding habits of the Neotropical otter (Lontra longicaudis annectens) in the Bavispe-Yaqui River, Sonora, Mexico. Therya 4:297-309.

Roth, J. D., D. L. Murray, And T. D. Steury. 2008. Spatial dynamics of sympatric canids: Modeling the impact of coyotes on red wolf recovery. Ecological modelling 214: 391-403.

Rzedowskı, J. 1978. Vegetación de México. Ed. Limusa. Ciudad de México, México.

Saint, A. D. H. 2006. Hábitos alimentarios del puma (Puma concolor) en la sierra de Nanchititla. Tesis de Licenciatura. Universidad Autónoma del Estado de México.

Schoener, T. W. 1974. Resource partitioning in ecological communities. Science 185: 27-39.

Servín, J. E., N. Chacón, N. Alonso-Pérez, and C. Huxley. 2003. New records of mammals from Durango, Mexico. The Southwestern Naturalist 48:312-313.

Smiroldo, G., A. Balestrieri, L. Remonti, and C. Prigioni. 2009. Seasonal and habitat-related variation of otter Lutra lutra diet in a Mediterranean river catchment (Italy). Folia Zoologica 58:87-97.

Stephens, D. W., And J. R. Krebs. 1986. Foraging Theory. Princeton University Press. New Jersey. U.S.A.

Tinker, M. T., G. Bentall, And J. A. Estes. 2008. Food limitation leads to behavioral diversification and dietary specialization in sea otters. Proceedings of the National Academy of Sciences 105:560-565.

Trinca, C. S., H. F. Waldemarin, and E. EiziRIK. 2007. Genetic diversity of the Neotropical otter (Lontra longicaudis Olfers, 1818) in Southern and Southeastern Brazil. Brazilian Journal of Biology 67:813-818.

Weber, L. I., C. G. Hildebrand, A. Ferreira, G. Pedarassi, J. A. Levy, AND E. P. Colares. 2009. Microsatellite genotyping from faeces of Lontra longicaudis from southern Brazil. Iheringia Serie Zoologia 99:5-11.

Yom-Tov, Y., T. M. Heggberget, Ø. WiIg, and S. Yom-Tov. 2006. Body size changes among otters, Lutra lutra, in Norway: the possible effects of food availability and global warming. Oecologia 150:155-160.

Young, J. K., S. N. Glasscock, AND J. A. Shivik. 2008. Does spatial structure persist despite resource and population changes? Effects of experimental manipulation on coyotes. Mammalogy 89:1094-1104.

Associated editor: Rafael Avila Flores

Submitted: March 5, 2019; Reviewed: April 11, 2019;

Accepted: July 7, 2020; Published on line: November 20, 2020. 
DIET VARIATION OF OTTER IN SINALOA

104 TTHERYA Vol. 12 (1): 95-102 